\title{
Under the Trend of Producer Services, Exploring Logistics Management Professional Building Program of Private Universities
}

\author{
Hong Wang ${ }^{1,}$, Lina Chang ${ }^{2, b}$, Fuhui Jing ${ }^{3, ~ c}$, Shouquan Wang ${ }^{4, d}$ \\ Qingdao Huanghai University, Qingdao, Shandong, China \\ awh201209@163.com, bchanglina1111@163.com, '864352776@qq.com, ${ }^{\mathrm{d}}$ sgr100125@126.com
}

Keywords: Producer services, Universities, Logistics professional construction management, Curriculum system, Double-teacher building, Training building

\begin{abstract}
Resources and environmental issues are increasingly becoming the focus of global, global economy is moving from the "industrial and agricultural economy" to the tertiary industry" service economy". Modern services include consumer services and producer services. Modern logistics industry is one of the major producer services, its development must depend on the appropriate logistics professionals, so building logistics professionals adaptation producing services is imperative.

Under the trend of producing services in the global economy, we need to review, modify, enrich and perfect the logistics management professional training scheme and teaching course system. This article first expounds the concept of producing services and the relationship between logistics and producer services, then, discusses the construction of teachers team construction and practical teaching system, from the perspective of the curriculum system, and thereby builds logistics management subject construction scheme for the private colleges under modern service industry development trend.
\end{abstract}

\section{Introduction of Producing Services}

Currently the world's first and second industry has turned to medium speed development from the high speed development, followed by resource depletion, environmental destruction and transparent profit. So the world began to seek new economic growth point, and environmental friendly "service economy" has become the trend. Modern service industry, especially producing service has become the third profit source of global development. Now the global services account for $60 \%$ of GDP on average, and this ratio is over $70 \%$ for some well- developed countries. At the same time, producing services makes up $70 \%$ of the services industry in developed countries. Obviously, producing service has become the leading industry and highlight point of economy growth in the developed world, and it is the symbol of the international metropolis industry development[1].

The Meaning of Producer services. Producing services belong to Industry 2.5, which means providing service for manufacturing and commodities circulation in the first and second industry, other than providing consuming service for social individuals. producing services focuses on providing services for physical producing and servicing producing [2].

Modern Logistics Industry Has Become the Emerging Producer services. As one of the important components of the services sector, for a long period, the logistics industry has been acting as a traditional consuming based industry, whose performance has shown a declining tendency from 2011.Whereas, modern logistics industry starts to serve production, and turns to the producing service industry. As the emerging industry, producing services are expected to have a bright prospect. With the booming development of producing services such as the international logistics, commercial services and, financial services, professional logistics personnel are in short. To meet this demand, private colleges have to build a set of corresponding subject construction plan. . 


\section{Logistics Management Subject Construction Corresponding for the Development of Producer Services}

Several shortcomings exists in logistics management curriculum construction, in one side the subject content is simple and shallow, there is no specified producing services related content. In the other side, students themselves are not good at applying theory into practice, what's more, the certificate mechanism for teaching qualification and logistics professional qualification is not good enough. This paper seems to cope the subject construction in terms of curriculum system, teaching personnel system and practice teaching system .

Curriculum System Optimization, Improve Its Flexibility and Social Adaptability. First, keep pace with current economy development on the basis of "wide diameter, thick foundation". Logistics subject is a comprehensive discipline, it is an integration of economy, technology, information, marketing, finance and law. At the same time, it has a high requirement for practice. Based on "wide diameter, thick foundation", logistics curriculum should keep pace with current development trend of logistics industry, take ideas of "theory ties practice, learning in practice and double certificate qualification combined". Only by modifying and perfecting the curriculum continuously can colleges establish teaching mode that qualify students for professional logistics jobs. In practice, colleges could add courses like financial logistics, port logistics, the property law to the curriculum system, in addition to Logistics Case and Practice In that way, the curriculum is in sync with development of society, economy, science and technology. And the students will be qualified to producing services jobs in areas of logistics finance, logistics intelligence and logistics estate.

Second, learn from foreign advanced mature curriculum system. First of all, logistics professional curriculum system includes not only logistics professional basic professional knowledge, relevant knowledge such as interpersonal communication, business communication is also important. Second, we should learn from foreign mature logistics curriculum, more attention should be put on logistics strategic teaching, so courses like Logistics Strategy Management should be added to the list of curriculum. In this way students will be able to solve logistics problems in respect of long term strategy. Finally, colleges should substitute functional subjects such as transportation, warehousing and distribution with management courses such as procurement and material supply, which is commonly practiced in developed countries.

The third, combine regional advantages with subject professional characteristics. As a private local college, with obvious regional advantages and regional characteristics, it will serve the local economy development. Therefore, the value orientation of logistics professional education is to serve the local employment, and it should be fully embodied in the logistics professional curriculum system. students should be leading to focus on the logistics professional compulsory course ,such as international logistics, port logistics, container transport, port business management and practice management and international freight forwarders and other courses in coastal areas of university logistics professional curriculum system. Private colleges logistics professional skilled personnel training project must comply with the trend of regional economic development, with variability and openness, and be revised according to the local industrial structure and market demand.

In a word, "wide diameter, thick foundation" should be the foundation of curriculum construction, at the same time, select development direction according to the local economic construction and the development trend and set curriculum system in line with the development of modern high-tech service industry are necessary to guarantee the cyclical synchronization of social development and talent training.

Teaching Qualification and Logistic Professional Qualification Talents Cultivation for the Development of Local Producer services. With the rapidly global development of the modern producing service industry, logistics professionals are in short, and teachers qualified with relevant experience and knowledge of producing services are not enough, and all these result in the poor quality of logistics professional training.Therefore the following aspects on training teachers with both teaching qualification and logistics professional qualification are provided . 
First, guarantee of the quality and quantity of teaching personnel in vocational colleges.

At present, the teachers' professional talent training mode should be reformed. For example, double qualification certificate professional logistics can be set up in universities. In one aspect, students will obtain the teaching qualification certificate when graduate from college with required credit points; in another aspect, he would get the logistics professional qualification certificate. In this way, semester internship on related jobs and areas are necessary. With both theory and practice experience accumulation, the graduates can take the role of both teachers and logistics professional personnel. In this way, the lack of high quality teachers in vocational college can be solved completely.

Second, professional Evaluation in theory and training implement at the same time.

Evaluation and assessment of logistics professional teachers' comprehensive abilities should be put in the first place. Skill graded evaluation is mainly suitable for teachers have practical operation skills, meanwhile, referencing the assessment results of teachers' basic skills. Current professional evaluation is mainly suitable for younger teachers engaged in teaching and scientific research, examining their actual operation ability, too. The two methods carry out at the same time, to examine and evaluate teachers' theory and practice level. Before the related national policy unveiled, colleges and universities can render the relevant treatment to teachers first, and link professional evaluation to their payment and personal promotion, in order to stimulate teachers' theory and practice level.

The third, to perfect mechanisms of incentive and training. In terms of incentive mechanism, we can draw lessons from foreign " Double-qualified Teachers" incentive mechanism. For example: the "Double-qualified " teachers of vocational colleges is of higher social status, and salary income in Germany, their identity is equivalent to civil servants, their legal status is determined by the national civil servant law. In Japan, "Double-qualified" teachers' assessment and promotion directly determine the wage level [3]. Now, Chinese civilian-run colleges and universities are trying to improve the treatment for" Double-qualified" teachers, and gradually form the corresponding incentive mechanism.

In terms of in-service teacher training, civilian-run colleges and universities mainly offer compensation education in China, far away from the essence of enhancing application, sending logistics professional teachers to practice in production enterprise, service enterprise and scientific research institutions is quite a good choice, then form a long-term system of this attempt and upgrade teachers' knowledge structure and practical ability continuously, so as to ensure the teaching staff keep pace with the times fundamentally .

The forth, management system: Adopt tenure system in civilian-run colleges and universities. Adoption of tenure system in teachers in developed countries has been a long time, and achieved satisfactory results. For example, since 1970, the disadvantages of lifelong employment system became increasingly obvious, and higher education in Japan transformed from elite education to mass education. After 1990,tenure system in teachers became more and more adapt to the reform and development of economy and higher education, so the tenure system was more and more widely used in Japan. American colleges and universities also implement the tenure system in teachers, and the contracts are mainly in short. In other words: Sign short-term contracts and decide whether teachers leave based on the requirements of colleges and universities, condition of scientific research funds and teachers' ability[3].

Therefore, draw lessons from the relevant experience of developed countries, and combined with national conditions of China, implement tenure system in civilian-run colleges and universities can promote the formation and development of system of double-qualified teachers.

The fifth, improve the proportion of part-time logistics teachers in civilian-run colleges and universities. At present, because of various reasons, the proportion of part-time teachers in higher vocational colleges is just between $20 \%$ and $30 \%$, much lower than that in abroad. For example: the number of part-time teachers in higher vocational colleges is 1.7 times of full-time teachers in Japan. In the United States and Canada, full-time teachers in higher vocational colleges just $30 \%$ of the whole teachers, this proportion in related enterprises and institutions is more than $60 \%$. 
As an important skill type talents training base, civilian-run colleges and universities must take full attention to recruitment work, to introduce part-time teachers who embark on correlation specialty, making the theory keep seamless connection with practice, and bring frontier knowledge of logistics into the classroom. It is a conducive way to make teachers transform from full-time to "double-qualified".

In short, under the situation of the producing services develop rapidly in the global, civilian-run colleges and universities should stick to the principle of "introduction to and going out", pay attention to the cultivation and promotion of teachers' training level, practical ability and related skills, establish a powerful double-qualified teaching staff in logistics management specialty, connect logistics education with industry demand, so as to cultivate logistics students that can combine theory with practice, gather education with skills.

Perfect the Practice Teaching System Under the Modern Logistics Development Trend. Due to the characteristics of logistics management that lay stress on practice, application and comprehensiveness, especially when the producing services become the symbol of the regional development, we should strengthen the system of practical teaching and lay stress on cultivating students' practical ability. On one hand, we must pay attention to the construction of practice training bases out of campus, on the other hand, develop the training base in campus, then forming a practical teaching system of "lab+ intramural practice base +off-campus practice base”.

First, construction of intramural labs. The four major functions of colleges and universities: talent training, cultural inheritance, social service, scientific research, are inseparable from the support of the labs. Civilian-run higher vocational colleges can set up labs with perfect equipment and sound functions through the construction of hardware and teaching resources, then realize the combination of logistics, business flow, cash flow and information flow in logistics training base [4], and become an important training base for skilled talents.

For example, opening several laboratories to students major in port logistics, such as logistics software laboratory (including seven functions), logistics storage laboratory, e-commerce laboratory, international trade model table lab, customs declaration lab, international logistics laboratory, container freight technique laboratory, commercial chain management system, exhibition hall of logistics culture and function, and other related training bases about producing services of logistics. In this case, realize the coordination of the business flow, information flow and material flow in logistics operation, eventually build distinctive lobs that cross-discipline, cross-platform, can serve for regional economy, which also have the functions of scientific research and practical teaching [5].

The second, the construction of the intramural practical training base. The building of practical training base in college is an important link in practical teaching system. Such as the building of practical training base of the China Post. Private colleges and universities can cooperate with China Post Express logistics company to establish business outlets in the school, engaged in international and domestic express delivery business, open up the special field that managed and operated by the students, complete the school students and social express delivery business. It is become a reality to quickly apply the knowledge of the students learned in the Postal Distribution Center internship to work, combination of practice and theory, in order to promote learning.

In addition, private colleges can construct the campus Courier, Alibaba e-commerce platform, freight forwarding, supply chain management, ERP, CRM, and other practical training platform, it can build modern logistics technology training center and multiple logistics management training platform.

The third, the construction of practice base off-campus. In order to adapt to the development trend of the global producer services, we can create the following types of practice base:

Typical company based on manufacturing industry: such as daily products, electronic products ( Haier), daily necessities, assembly type enterprises, such as Shanghai Volkswagen Santana, textile, etc.; The port type of enterprise or company: such as the international ocean shipping company, ship leasing company, container leasing company, owner, liner, etc.; Modern logistics company: such as multinational logistics enterprises (China Master Logistics Co.,LTD), express company (China Post, 
ZTO express, STO express, SF express, etc.), distribution center, logistics center, etc.; International freight and agency company: all kinds of forwarder company; Consulting company: such as Qingdao mau auspicious logistics consulting company; Financial pledge supervision company: such as Beijing Sunshine International Freight co., Ltd.

Through the construction of practical training base, which can realize the unification of book theory and practice operation, enhancing university-enterprise depth fusion, construct the communication mechanism of university-enterprise and the exchange platform, perfect "total office, sharing, produced, co-management" cooperation mechanism, realize common development.

\section{Conclusions}

In a word, the construction of private colleges logistics management specialty should take the development trend of producer services as a starting point, based on regional economy, and pay attention to requirements of the national industry and policy, improve the professional construction scheme gradually, It is an indispensable duty for private colleges and universities to promote the development of producer services in China.

\section{Acknowledgments}

Undergraduate College Teaching Reform Project of Shandong Province (Project Number:2015M082);Financed by the Fund of International Training Plan for Excellent Younger Teachers in Colleges and Universities of Shandong Province University-enterprise Cooperation Project of Qingdao Huanghai University

\section{References}

[1] L.J. Shi. Development of modern service industry should be in producing services as a breakthrough. Cooperative economy and technology,2010,(14) (In Chinese)

[2] W.B. Xu. Growth phase transformation under the background of how to speed up the development of producing services --- The researcher to have visit to the state council development research center You-wei Lai.Bei Jing: China economic times,2013,11(5)(In Chinese)

[3] X.H. Lin. Foreign vocational college "double type" teachers team construction experience and enlightenment.Guang Zhou: City vocational college,2011.03.(In Chinese)

[4] G.J. Lian-xu Ma. Logistics management specialty construction scheme. TianJin:Tianjin binhai vocational college,2011,10.(In Chinese)

[5] Q.X. Gan. Based on the service of logistics professional laboratory construction of local economic development -- Taking an example of Guangxi institute of finance and economics. The rule of law and economic ( Under the ten-day),2013.03.(In Chinese) 